\title{
Charismatic leadership and organizational citizenship behaviour: examining the role of stressors and strain
}

\author{
Sabine Boerner, Elisabeth Dütschke* and Simon Wied \\ University of Konstanz, Germany
}

\begin{abstract}
This study analyses the impact of followers' stress on the relationship between charismatic leadership and organizational citizenship behaviour (OCB). Stressors are distinguished as the objective component of work stress, and strain as the subjective component of work stress. It is assumed that stressors will moderate the relationship between charismatic leadership and OCB (Hypothesis 1). In addition, it is hypothesized that followers' strain will mediate the relationship between charismatic leadership and OCB (Hypothesis 2). Results from a study interviewing 142 nurses from three German hospitals confirmed the second hypothesis: followers' strain fully mediated the relationship between charismatic leadership and followers' OCB.
\end{abstract}

Keywords: charismatic leadership; organizational citizenship behaviour (OCB); stressors; strain

Organizational citizenship behaviour (OCB) was defined by Organ $(1988,5)$ as an 'individual behavior that is discretionary, not directly or explicitly recognized by the formal reward system'. OCB is also referred to as 'extra-role behavior' of organizational members that 'in the aggregate promotes the effective functioning of the organization' (Organ 1988, 5). The existing body of research has provided much empirical evidence confirming that OCB enhances organizational performance in several organizational settings (e.g. DeGroot, Kiker, and Cross 2000; Lowe, Kroeck, and Sivasubramaniam 1996; Patterson et al. 1995). Thus, it is one of the challenges of human resource development (HRD) to find ways to encourage employees' OCB.

At the same time, as employees find themselves in more and more demanding work situations, the notion of high workload and stress comes to the fore (Russ-Eft 2001). Given a high amount of stress in the workplace, individuals are increasingly forced to devote their resources to coping behaviours (Lazarus 1991). They thus might refrain from engaging in extra-role behaviour, which intensifies the challenge faced by HRD. Against this background, our paper aims at investigating how employees' extra-role behaviour is threatened by stress and at analysing ways of dealing with this threat. In particular, we investigate the contribution of a charismatic leadership style (Waldman et al. 2001) to enhance followers' OCB in stressful work settings.

Charismatic leadership has been identified as an essential antecedent of OCB (e.g. Bettencourt 2004; Deluga 1995). Empirical studies provide support for a positive relationship

*Corresponding author. Email: elisabeth.duetschke@uni konstanz.de 
between charismatic leadership and followers' OCB (e.g. Den Hartog, Keegan, and De Hoogh 2007; De Cremer and Van Knippenberg 2002; Shamir et al. 1998). Charismatic leadership is defined as a 'relationship between an individual (leader) and one or more followers based on leader behaviors combined with favorable attributions on the part of the followers' (Waldman et al. 2001, 135). Followers of a charismatic leader tend to identify strongly with their leader, which motivates them to engage in extra-role behaviour (Bass 1985; Podsakoff, MacKenzie, and Bommer 1996). In the literature, charismatic leadership has often been treated as equivalent to transformational leadership (Yukl 1999; Barling, Weber, and Kelloway 1996). Recent theoretical and empirical work, however, has contributed to further understanding the similarities and differences between charismatic and transformational leadership. For example, Rowold and Heinitz (2006) found that the constructs charismatic leadership and transformational leadership share a high amount of variance, but have a different impact on profit. Judge et al. (2006) argue in favour of a clear conceptual distinction between two dimensions of transformational leadership, vision and charisma. In this paper, we focus exclusively on charismatic leadership as defined by Waldman et al. (2001).

According to Shamir's self-concept-based motivational theory of charismatic leadership (Shamir, House, and Arthur 1993), the positive relationship between charismatic leadership and followers' OCB can be explained as follows: First, charismatic leaders enhance follower identification with the leader and trust in the leader. As was found by Sosik $(2005,228)$, followers are willing to engage in OCB 'because of their favorable perceptions of the leader, based on their trust, loyalty, and obedience to the leader'. Second, charismatic leaders provide effects on followers' identification with their task or role, 'namely increased efficacy perceptions, intrinsic motivation, and willingness to sacrifice themselves to perform the task' (Shamir, House, and Arthur 1993, 388; House, Spangler, and Woycke 1991; Conger 1989). Third, charismatic leaders put emphasis on the collective identity of the group or unit and its superiority to other groups. Thus, charismatic leaders strengthen followers' relationship with the collective, namely increased identification with the group and attachment to it. Accordingly, employees' collective identification and group belongingness have been proposed and identified as (partial) mediators between charismatic leadership and OCB (Todrovic and Schlosser 2000; De Cremer and van Knippenberg 2002; Den Hartog, Keegan, and De Hoogh 2007; Shamir et al. 1998).

Nevertheless, the mechanisms by which charismatic leadership may enhance followers' OCB are not yet sufficiently clear (e.g. Podsakoff et al. 2000; Den Hartog, Keegan, and De Hoogh 2007). Similarly, to date little is known about the particular contextual factors of this relationship. As literature on leadership suggests (Porter and McLaughlin 2006), the same leadership style may generate different effects under different contextual conditions. Empirical studies identified managerial performance, environmental uncertainty and followers' need for leadership as moderators of the relationship between charismatic leadership and OCB (Sosik 2005; De Hoogh et al. 2004; De Vries et al. 1999). As several authors have suggested to focus on mediating and moderating processes concerning leadership effectiveness (Kark, Shamir, and Chen 2003; Yukl 1999; Porter and McLaughlin 2006), our study aims at further investigating mediators and moderators in the relationship between charismatic leadership and followers' OCB. Following this perspective, we analysed the influence of followers' stress on the relationship between charismatic leadership and followers' OCB.

According to the tradition of research on work stress (Gebert 1981; Beehr 1998), we distinguish job stressors from strain in the workplace. Job stressors refer to the environmental demand or the objective workload an employee has to face, i.e. the degree to which his or her work environment requires cognitive, emotional or physical effort 
(De Jonge and Dormann 2006). In contrast, strain is defined as a worker's subjective reactions to stressors (Lazarus 1991; Terry and Jimmieson 1999). In this paper, we examined the impact of both objective stressors and subjective strain on the relationship between charismatic leadership and employees' extra-role behaviour. To the best of our knowledge, employees' stress has been analysed neither as mediator nor as moderator in this context before. Concentrating on the stress perspective, our study thus contributes to the existing body of knowledge on charismatic leadership and followers' OCB.

We assumed that stressors would moderate the relationship between charismatic leadership and followers' OCB: if followers experience a high level of stressors, a charismatic leader may not be able to enhance extra-role behaviour (Hypothesis 1). Instead, followers' strain is likely to mediate this relationship: Charismatic leaders may contribute to reduce followers' level of strain and thereby facilitate OCB (Hypothesis 2). We tested these hypotheses surveying 142 nurses from 18 departments in three German hospitals. Implications are discussed regarding antecedents to OCB as well as regarding human resource development.

\section{Charismatic leadership, organizational citizenship behaviour and stress}

The concept of charismatic leadership is a prominent representative of the new theories emerging in leadership research in the last two decades (Dvir et al. 2002). Charismatic leaders are described as articulating a vision and a sense of mission, showing determination and communicating high performance expectations (Waldman et al. 2001). They inspire their followers to achieve extraordinary outcomes by providing meaning, understanding and identification with organizational goals (Shamir, House, and Arthur 1993). Moreover, they offer support, mentoring and coaching, which in turn contributes to follower's self-esteem. Thus, followers of charismatic leaders strongly identify with the vision and the organization (Waldman et al. 2001). As a result, followers are willing to invest considerable time and energy on behalf of the organization and to make even personal sacrifices in order to reach organizational goals (Conger 1989). Accordingly, charismatic leadership is positively related to organizational performance (e.g. House et al. 1991; Howell and Frost 1989; Kirkpatrick and Locke 1996). Moreover, empirical studies have confirmed a positive relationship between charismatic leadership and followers' OCB (e.g. Deluga 1995; Sosik 2005).

OCB is usually defined as a multidimensional concept (e.g. Deckop, Mangel, and Cirka 1999; Podsakoff et al. 2000). Staufenbiel and Hartz (2000) identified four dimensions of extra-role behaviour: (1) helping behaviour; (2) sportsmanship; (3) conscientiousness; and (4) civic virtue. Results from empirical research show that each of these dimensions is correlated positively with organizational performance (MacKenzie, Podsakoff, and Ahearne 1998; Podsakoff et al. 2000).

Helping behaviour is defined as supporting colleagues with their work and assisting newcomers. A high level of helping behaviour is therefore likely to promote a smooth work flow within the organization and to reduce the need for both administrative control and process coordination. Sportsmanship includes tolerating inconveniences at the workplace without complaining. Hence, sportsmanship may enhance organizational performance, as workers will be less distracted from their tasks. Conscientiousness implies careful use of organizational resources (e.g. time, supplies) and thus contributes to organizational performance. Civic virtue involves volunteering for additional vocational training or making suggestions to improve the work flow. Again, improvements in organizational performance are likely to result. 
In the discussion about stress in the workplace, objective job stressors are distinguished from subjective strain. Job stressors result from environmental demands (De Jonge and Dormann 2006) such as noise, time pressure, physically demanding work or interruptions and a high risk of errors (cf. Beehr 1998). The type of stressor and the degree of stress an individual is exposed to varies according to the organizational setting and the particular work task (Singh Kang and Singh 2004; Büssing and Glaser 1999). In the hospital context, high workload is known to be a frequent stressor (Baldwin 1999; Hipwell, Tyler, and Wilson 1989; Tyler, Carroll, and Cunningham 1991).

Strain, in contrast, is defined as the employees' subjective reaction to stressors (Lazarus 1991; Terry and Jimmieson 1999). Strain may appear in the form of psychological, physiological and behavioural reactions (Koslowski 1998). Psychological reactions to enduring and extreme strain are, for example, anxiety, depression, exhaustion or loss of self-confidence. Physiological symptoms of strain include headaches, insomnia and heart disease (e.g. Udris and Frese 1999; Schat, Kelloway, and Desmarais 2005). Frequent behavioural responses to strain are withdrawal from or avoidance of the stressor, resulting in, for example, absenteeism and turnover.

The level of strain a worker experiences depends on the kind and amount of stressors he or she experiences at his or her workplace. However, the level of strain is not determined entirely by these stressors. Strain also depends on the follower's perception and appraisal of the stressful situation. Due to interpretation processes, an individual may feel either challenged or threatened by the same stressor (Lazarus 1991). This interpretation may be influenced by individual traits and dispositions (e.g. positive affect and conscientiousness, Zellars et al. 2006), as well as situational characteristics (e.g. social support, economic situation of the organization, Cobb 1976; Payne 1999).

\section{Stressors as moderators}

If an employee is exposed to stressors, he or she is likely to engage in coping behaviours in order to handle the stressful situation (Lazarus 1991). If an employee has more individual resources (for example, time and energy) to invest in such coping behaviours, fewer resources will be available to engage in extra-role behaviour. In a stressful situation, it thus seems likely that an employee tends to limit his or her efforts to in-role behaviour instead of extra-role behaviour. He or she may thus feel less able to engage in extra-role behaviour.

In this situation, even a charismatic leader will have difficulties to stimulate followers' OCB. Charismatic leaders will contribute to enhance followers' level of identification with the leader, the task and the group (Shamir, House, and Arthur 1993). However, given high levels of stressors, employees will lack the resources to translate their identification into extra-role behaviours. We therefore assume the positive impact of charismatic leaders on OCB to be lower if followers experience a high level of stressors. To conclude, we expect that stressors will moderate the relationship between charismatic leadership and OCB.

Hypothesis 1: Stressors will moderate the relationship between charismatic leadership and followers' OCB such that this relationship will be weaker when stressors are elevated.

\section{Strain as a mediator}

The level of strain a worker experiences is likely to reduce his extra-role behaviour. If an employee feels tired, exhausted or anxious, he or she will no longer engage in OCB. Although strain is defined as an individual response to stressor stimuli (Beehr 1998), the resulting level of strain is not entirely determined by the intensity of stressors. Rather, as 
mentioned above, perceived strain also depends on the followers' individual perception and appraisal of the stressors (Lazarus 1991).

Leaders may influence this interpretation process, resulting in followers feeling more challenged than threatened by the stressors they face in their job. Accordingly, supervisor support has been found to reduce followers' level of strain (Beehr 1976; Schirmer and Lopez 2001). We thus assume that charismatic leaders will contribute to reduce followers' strain, which in turn will impede losses in their OCB.

First, the social support (Gore 1978) provided by a charismatic leader will contribute to reduce the level of strain followers experience. As defined, charismatic leaders tend to establish a positive, individualized relationship to each of their employees (Waldman et al. 2001). Charismatic leaders formulate high-performance expectations, and provide individual coaching and individual encouragement. They increase the self-confidence of the subordinates, strengthen collective and individual self-worth and efficacy of followers, and express hope and faith in their competences (Howell and Frost 1989; Shamir, Arthur, and House 1994; Den Hartog and Verburg 1997). Followers will thus develop confidence to manage the stressful situation. In addition, charismatic leaders provide warmth and trust in the relationship to their followers. In stressful situations, followers will thus count on their charismatic leader's encouragement and support. In terms of value-expectancy theory (Vroom 1964; Kominis and Emmanuel 2007), charismatic leaders will thus enhance followers' expectancy to reach defined goals even in the presence of stressors.

Second, charismatic leaders provide orientation and higher meaning in everyday-work (Bass 1985; Densten 2005). They communicate a vision, stressing the importance of the project, a common goal and a collective identity, moral justifications and values and a long-term goal orientation (Frese, Beimel, and Schoenborn 2003). They thus provide a more comprehensive understanding of job requirements. A study by Densten (2005) gives evidence for this effect. According to value-expectancy theory (Vroom 1964; Kominis and Emmanuel 2007), charismatic leaders underline the value of followers' efforts even in stressful situations.

Taken together, we assume that charismatic leaders will contribute to stimulate both followers' expectancy to reach defined goals even in the presence of stressors and the value they ascribe in these goals. Thus, charismatic leaders assist followers to interpret a stressful situation as a challenge rather than a threat. Hence, charismatic leaders will reduce followers' strain and thus impede reductions in followers' OCB. Accordingly, several researchers have shown that charismatic leadership is especially successful in enhancing followers' performance in situations that followers perceive as demanding (e.g. Bass 1985; Waldman et al. 2001). We therefore assume that charismatic leaders enable extra-role behaviour by reducing followers' strain at the workplace. The positive impact of charismatic leadership on OCB lies in suppressing the mediator strain. In other words, we expect the effect of charismatic leadership on followers' OCB to be mediated by the reduction of followers' strain.

Hypothesis 2: Followers' strain will mediate the relationship between charismatic leadership and followers' OCB.

\section{Method}

\section{Sample}

Data for his study were collected from $n=142$ nurses in 18 work-groups from three German hospitals. We chose this sample because both stress and strain are frequently 
discussed topics in this organizational setting (e.g. DAK-BGW 2000; Winwood and Lushington 2006; Hallin and Danielson 2007). Additionally, it has been demonstrated that OCB has a considerable impact on the quality of nursing (Bolon 1999; McNeese-Smith 1999). Nevertheless, workers' organizational identification in healthcare organizations is reported to be poor, and efforts to better prepare leaders at all levels in healthcare organizations are called for (McAlearney 2006). The respondents in our study ( $83 \%$ were female) had been working as nurses for an average of 13 years $(\mathrm{SD}=9.6)$ and for an average of nine years $(\mathrm{SD}=7.3)$ in the organizations under study. The average respondent was 35 years old $(\mathrm{SD}=10)$.

All hospitals under study were participating in a total quality management programme, which required interviewing employees about work issues. Accompanying this survey, we had the opportunity to include the items for our study in the questionnaire. In two of the hospitals, questionnaires were handed out to employees at the workplace. Employees were allowed to choose whether they filled them in during working hours or at home. In the third hospital, employees had the possibility to fill in the questionnaires at a polling station established for this purpose. Participation was voluntary and anonymous. In each hospital, the survey was supported by hospital management and by workers' representatives.

\section{Measures}

All items were scored on a six-point Likert-scale (reaching from $1=$ 'totally disagree' to $6=$ 'totally agree'). We measured extra-role behaviour using a shortened version of Staufenbiel and Hartz's (2000) OCB-scale. Staufenbiel and Hartz developed and validated this measure building on the scale by Podsakoff et al. (1990). Each of the four OCBdimensions explained above was measured by four items. Examples were 'I help others who face heavy workloads' (helping behaviour), 'I do not complain about trivial matters' (sportsmanship), 'I try to keep abreast of changes within the hospital' (civic virtue) and 'I do not take extra breaks' (conscientiousness). Due to the hospital context, minor adaptations in the wording were necessary (e.g. replacing 'organization' by 'hospital'). We aggregated all items into a comprehensive general measure of OCB (cf. Deckop, Mangel, and Cirka 1999).

To measure charismatic leadership we used five items by Waldman et al. (2001) (e.g. 'I have complete confidence in my supervisor'; 'My supervisor transmits a sense of mission'). We translated the items into German applying the parallel blind technique recommended by Behling and Law (2000). We used three items to measure followers' strain: 'When I come home from work I am often too tired to do anything else', 'I feel exhausted after work' and 'My job makes me feel worn out at the end of the day'. To assess the intensity of stressors, we chose five items that represent heavy workload in the hospital context: 'I have to work under severe time pressure'; 'I have to do physically demanding work'; 'I often cannot finish my assignments because of interruptions'; 'I frequently have to do several things at the same time' and 'Small errors can have a strong impact on task accomplishment'.

Cronbach's alphas ranged from 0.77 to 0.91 for OCB, charismatic leadership and strain (see Table 1). For the stressors scale, however, the internal consistency was only moderate (Cronbach's $\alpha=.65$; see Table 1). This result is not surprising, as Cronbach's alpha is a measure for the homogeneity of the items included in a scale. Considering the heterogeneity of the stressors included in this study (see above), we did not expect a highly consistent scale. 
Table 1. Descriptive statistics and inter correlations for all study variables.

\begin{tabular}{lccccccc}
\hline & $\mathrm{M}$ & $\mathrm{SD}$ & $n$ & 1 & 2 & 3 & 4 \\
\hline 1 Organizational citizenship behaviour & 4.89 & .43 & 137 & .77 & & \\
2 Charismatic leadership & 4.43 & .93 & 137 & $.239^{* *}$ & .91 & \\
3 Stressors & 4.81 & .75 & 139 & .059 & .076 & .65 & \\
4 Strain & 3.78 & 1.12 & 142 & $.219^{*}$ & $.355^{* * *}$ & $.422^{* * *}$ & .86 \\
\hline
\end{tabular}

Note: Alpha coefficients appear in italics along the main diagonal.

1 totally disagree; 6 totally agree

$* * * p<.001 ; * * p<.010 ;{ }^{*} p<.050$.

\section{Analysis}

The expected moderation effect (Hypothesis 1) was tested conducting a hierarchical regression analysis (Jaccard and Turrisi 2003). The assumed mediating effect (Hypothesis 2) was tested following the procedure proposed by Baron and Kenny (1986). To test for mediation, Baron and Kenny (1986) recommend calculating the following three regression equations: (1) regressing the mediator on the independent variable; (2) regressing the dependent variable on the independent variable; and (3) regressing the dependent variable on the mediator and the independent variable. If the first and the second steps are significant and, controlling for the influence of the mediator in the third step, the original relationship between independent variable and dependent variable is reduced to no significance, a perfect mediation is confirmed. However, in practice, partial mediation is found more often. Partial mediation is established if, controlling for the influence of the mediator, the relationship between independent variable and dependent variable is still significant, however significantly reduced in size. Additionally, since the independent variable is supposed to influence the mediator, the independent variable and the mediator are expected to be correlated as well. Furthermore, to test whether a mediator carries the influence of the independent variable to the dependent variable, the Sobel test (Sobel 1982) is conducted. For hypothesis testing, we used raw-scores in the regression analyses.

\section{Results}

\section{Preliminary analyses}

\section{Confirmatory factor analysis}

To test the construct validity a confirmatory factor analysis (CFA) was conducted for the newly developed measures, stressors, strain and charismatic leadership. A three-factor model reached acceptable, though mediocre fit indices (CFI $=0.92$, RMSEA $=0.09$, $\left.\mathrm{C}_{\min } / \mathrm{df}=2,1\right)$. This model was compared to an alternative one-factor model including all items into one scale and a two-factor model combining strain and stressors into one factor. However, as expected, the alternative models did not fit the data well (one factor model: $\mathrm{CFI}=0.58, \mathrm{RMSEA}=0.20, \mathrm{C}_{\mathrm{min}} / \mathrm{df}=6.5$; two-factor model: $\mathrm{CFI}=0.84$, RMSEA $\left.0.123, \mathrm{C}_{\mathrm{min}} / \mathrm{df}=3.1\right)$. These results confirm satisfying discriminative validity for the three newly developed scales.

\section{Descriptive statistics}

Table 1 presents mean scores, standard deviations and zero-order inter-correlations of all study variables. For further analyses, all variables were centred on zero. 
As expected, the correlation between stressors and strain was moderate: the two variables shared only $17 \%$ of variance $(r=.42, p<.001)$. This finding confirms our assumption that followers' strain does not entirely result from the intensity of stressors, but is influenced by additional variables. Thus, it seems reasonable to separately analyse the effects of stressors and strain on the relationship between charismatic leadership and OCB.

\section{Hypotheses tests}

To test the expected moderating effect of stressors in the relationship between charismatic leadership and OCB, OCB was regressed on charismatic leadership, stressors (see step 1, Table 2) and the interaction of the two variables (see step 2, Table 2). Whereas charismatic leadership turned out to be a significant predictor of $\operatorname{OCB}(\beta=.263, p<.01$; see Table 2), the interaction between charismatic leadership and stressors was not significant. Thus, stressors did not moderate the relationship between charismatic leadership and OCB. Rather, the positive effect of charismatic leadership on OCB was independent of the intensity of stressors. Hypothesis 1 was therefore not supported by our data.

We tested the assumed mediating effect of followers' strain on the relationship between charismatic leadership and OCB (Hypothesis 2) following the three-step-procedure proposed by Baron and Kenny (1986) explained above. We found (1) a significant relationship between charismatic leadership and the assumed mediator (strain) $(\beta=-.355, p<.001$; see Table 3 , step 1) and (2) between charismatic leadership and $\operatorname{OCB}(\beta=.239, p<.001$; see Table 3, step 2). Charismatic leadership was also significantly correlated to the mediator strain $(r=-.355, p<.001$; see Table 1$)$. We further tested the mediation effect (3) by regressing OCB on charismatic leadership and strain (see Table 3, step 3). When both variables were included into the regression model (see Table 3, step 3), the significant effect of charismatic leadership on OCB disappeared. Hence, all three conditions for a full mediating effect as defined by Baron and Kenny (1986) were met by our data.

Table 2. Multiple regression analysis of moderation (Hypothesis 1).

\begin{tabular}{lcllccc}
\hline Step & Dependent variable & Independent variable & $\beta$ & $t$ & $R$ & Adjusted $R^{2}$ \\
\hline 1 & OCB & Charismatic leadership & .243 & $2.8^{* *}$ & .250 & .048 \\
& \multirow{2}{*}{ OCB } & Stressors & .088 & 1.1 & & \\
& & Charismatic leadership & .263 & $3.0^{* *}$ & .264 & .048 \\
& Stressors & .076 & .9 & & \\
& Charismatic leadership $\times$ & .091 & 1.0 & & \\
& stressors & & & & \\
\hline
\end{tabular}

Note: $\beta \quad$ Standardized regression coefficient.

$* * * p<.001 ; * * p<.010 ;{ }^{*} p<.050 ; n 131$.

Table 3. Multiple regression test of mediation (Hypothesis 2).

\begin{tabular}{lcllllc}
\hline Step & Dependent variable & Independent variable & $\beta$ & $t$ & $R$ & Adjusted $R^{2}$ \\
\hline 1 & Strain & Charismatic Leadership & .355 & $4.4^{* *}$ & $.355^{* * *}$ & .119 \\
2 & OCB & Charismatic Leadership & .239 & $2.8^{* *}$ & $.239^{* *}$ & .050 \\
3 & OCB & Charismatic Leadership & .173 & 1.9 & $.294^{* *}$ & .072 \\
& & Strain & .183 & $2.0^{*}$ & & \\
\hline
\end{tabular}

Note: $\beta \quad$ Standardized regression coefficient.

*** $p<.001 ; * * p<.010 ; * p<.050 ; n 133$. 
Additionally, we conducted the Sobel test (Sobel 1982) to assess if strain carries the influence of the charismatic leadership to OCB. We found a significant result (Sobel test $z=1.8, p<.10$ ). This supports our second hypothesis, claiming that strain mediates the relationship between charismatic leadership and OCB.

\section{Discussion}

\section{Summary}

In this study, we analysed the impact of stressors and strain on the relationship between charismatic leadership and organizational citizenship behaviour (OCB). First, we expected stressors to impede followers' extra-role behaviour and thus to countervail a charismatic leader's effort to enhance followers' OCB. We assumed that high levels of stressors would prevent a charismatic leader from enhancing followers' OCB (Hypothesis 1). However, the assumed moderating effect of stressors was not confirmed in our study. In our sample, the beneficial effects of charismatic leadership on followers' OCB were not reduced given a high amount of followers' stressors.

However, only a limited selection of stressors could be included in our study. Thus, we may not have covered the complete range of possible stressors that are relevant in the hospital setting. It is therefore left to further research to explore if the assumed moderating effect of stressors will be confirmed if different stressors are considered (e.g. shift-working, role ambiguity or role conflict, death of patients; Glazer 2005; Siegall 2000; Gray-Toft and Anderson 1981; Tyler, Carroll, and Cunningham 1991).

Second, strain as the subjective perspective on stress was found to have a negative effect on followers' OCB. As expected, strain was confirmed to be a mediator of the relationship between charismatic leadership and OCB. Thus, our second hypothesis was supported. Charismatic leadership contributes to diminish the potentially detrimental effects that followers' strain may have on their extra-role behaviour. In this study, however, we only considered minor forms of follower strain, primarily exhaustion. Hence, further research will have to investigate if charismatic leadership is able to alleviate severe forms of strain such as psychosomatic diseases.

\section{Limitations}

Apart from the above-mentioned restricted range of stressors and forms of strain included, further limitations of our study have to be considered. To begin with, the within-person rating of all study variables can lead to a systematic overestimation of the relation between the variables in terms of single subject method consistency bias (McDonald 1999). However, an autocorrelative overestimation is not coercive in single subject designs. As shown in the literature, the correlation does not have to turn out considerably higher than if it is being categorized by different persons (cf. Fuller et al. 1996; Keller 1992). In order to address concerns regarding common method bias, Podsakoff et al. (2003) recommend the application of Harman's single-factor test (i.e. investigating a one-factor solution). As documented in the result section, confirmatory factor analyses did not confirm a onefactor solution in our study. This result allows for the conclusion that common method bias seems not to pose a serious threat to the substantive interpretation made based on the findings reported in the paper.

Second, the cross-sectional design of our study does not allow assumptions to be made about the causality of the relationships studied. Hence, a longitudinal design that measures dependent and independent variables at different times would have been more revealing 
than a cross-sectional study. The theoretical and practical implications developed in this paper are thus preliminary and tentative.

Third, all data were collected within a nested design (i.e. 3 hospitals, 18 groups, 142 participants). Analyses of variance (ANOVA) did not reveal any significant difference between the three hospitals in our sample. Nevertheless, the results of this study might be biased, as variances due to the group level were not accounted for in the analyses (cf. Yammarino, Dansereau, and Kennedy 2001). Future studies should therefore include larger sample sizes and conduct multilevel analyses (Bliese, Halverson, and Schriesheim 2002).

Fourth, we chose the hospital setting for our study because we expected both charismatic leadership and OCB to be of particular relevance in this context (Bolon 1999; McNeese-Smith 1999). It may well be that our results in part reflect the characteristics of this context. Before generalizing our results to other organizational settings, we therefore recommend replications of our study, including a broader variety of stressors and strains.

\section{Theoretical implications}

Charismatic leadership as an antecedent of OCB has been subject to research in the past. However, as many employees face a considerable amount of stress in their daily work, it is important to analyse how followers' stressors and strain may affect this relationship. As far as we know, this is the first study to investigate this question. Our results suggest that it is important to distinguish between stressors and strain, since objective and subjective aspects of followers' workload are affected differentially by charismatic leadership and have differential effects on OCB. Hence, the relationship between charismatic leadership and followers' OCB is affected differently by strain and stressors respectively.

Our study shows that the positive effect charismatic leaders may have on followers' OCB is due to the reduction of followers' strain (mediating effect). Strain reduces the level of OCB an employee is willing or able to perform. Charismatic leaders, absorbing followers' strain by providing social support and orientation, therefore contribute to remove a significant obstacle to followers' OCB. With this result, our study contributes to explain why and how charismatic leaders enhance followers' OCB and thus adds the reduction of strain to the list of possible mediators that have been analysed in previous studies (cf. De Cremer and van Knippenberg 2002; Den Hartog, Keegan, and De Hoogh 2007). By focusing on followers' stress, our study thus contributes to the existing body of knowledge on charismatic leadership and OCB. In their self-conceptbased motivational theory of charismatic leadership, Shamir, House, and Arthur (1993, 388) argue that charismatic leaders provide effects on followers' relationships with their task or role, 'namely increased efficacy perceptions, intrinsic motivation and willingness to sacrifice themselves to perform the task'. Revealing the strain-absorbing capacity of charismatic leadership, our results supply an additional explanation for this argument.

Whereas the extant literature has focused on mediators that enable followers' OCB, our study, investigating followers' strain, looks at barriers to followers' OCB. The positive effect of charismatic leadership is thus not to enhance, but to suppress the mediator. Pursuing this perspective, further research may discover additional mediators in the relationship between charismatic leadership and followers' OCB. By emphasizing this perspective, our study thus contributes to the knowledge about antecedents to OCB (Konovsky and Organ 1996; Organ and Ryan 1995). 


\section{Implications for human resource development (HRD)}

Given the rising strategic importance of human capital, human resource management is called for in order to recruit, develop and retain this valuable asset (Carmeli and Weisberg 2006). In particular, HRD is recognized as being able to foster and contribute to desired workplace attitudes and behaviours of employees (Bartlett and Kang 2004). Critical employee behaviours in organizations include both in-role and extra-role behaviours. In the context of human resource management, OCB has been identified as a central element of individual performance (Werner 2000) and organizational success (Organ 1988).

As HRD activities take place in more and more demanding work situations, it is necessary to take into account the influence of high workload and stress (Russ-Eft 2001). Given a high amount of stress in the workplace, human resources might not be used in an optimal way. However, workload and stress is a topic that has rarely been considered in the context of HRD (Russ-Eft 2001).

Against this background, our paper contributes to the literature on HRD by connecting the discussion on OCB with the notion of stress in the workplace. Exploring the negative relationship between strains and OCB, our paper demonstrates a problem that has rarely been addressed in the HRD context. At the same time, by identifying the negative relationship between charismatic leadership and strain, we suggest a possible solution to this problem. Since strain is confirmed to mediate the relationship between charismatic leadership and followers' OCB, charismatic leadership may be one of the possible remedies against strains that endanger followers' OCB. HR-managers are thus supposed to intervene in order to try to avoid destructive employee strain. Hence, a promising strategy in HR is to emphasize efforts on leadership training, including trainings in order to improve charismatic leadership skills.

Several studies have shown that training can improve leaders' abilities in charismatic leadership (Barling, Weber, and Kelloway 1996). For example, Dvir et al. (2002) demonstrated a general training to become more charismatic to be effective. Moreover, Barling, Weber, and Kelloway (1996) revealed that a particular aspect of charismatic leadership - intellectual stimulation - can be trained as well. Our study suggests that another aspect of charismatic leadership, namely communicating a vision and inspiring people to work for this vision, is particularly important in order to absorb followers' strain and hence enhance OCB. Developing and empirically confirming this argumentation, our study delivers a new motivation for leaders to engage in training for charismatic leadership. This is especially important, since it is well known that adults need to be highly motivated to change their behaviour (Frese, Beimel, and Schoenborn 2003). The results of our study may thus stimulate leaders to change their leadership behaviour by attending training.

As Frese, Beimel, and Schoenborn (2003) have recently shown, one factor of charismatic leadership - communicating a vision - can be improved with action training. Action training, based on action theory, is an approach used to improve communication skills in managers (Frese, Beimel, and Schoenborn 2003). Action learning consists of five components, action-oriented mental model, learning by doing, motivation by experiencing the difference between present state and future goals, feedback in training, supporting transfer and the necessity to routinize behaviour (Frese, Beimel, and Schoenborn 2003). Leaders that intend to improve their charismatic skills especially under the perspective of reducing followers' strain, should therefore consider this form of leadership training. 


\section{Acknowledgements}

We would like to thank Annina Klasen for her assistance in the literature search.

\section{References}

Baldwin, P.J. 1999. Nursing. In Stress in health professionals, ed. J. Firth Cozens and R.L. Payne, 93 104. Chichester: John Wiley \& Sons Ltd.

Barling, J., T. Weber, and E.K. Kelloway. 1996. Effects of transformational leadership training on attitudinal and financial outcomes: A field experiment. Journal of Applied Psychology 81, no. 6: 82732.

Baron, R.M., and D.A. Kenny. 1986. The moderator mediator variable distinction in social psychological research: Conceptual, strategic, and statistical considerations. Journal of Personality and Social Psychology 51, no. 6: 117382.

Bartlett, K.R., and D. Kang. 2004. Training and organizational commitment among nurses following industry and organizational change in New Zealand and the United States. Human Resource Development International 7, no. 4: 42340.

Bass, B.M. 1985. Leadership and performance beyond expectations. New York: Free Press.

Beehr, T. 1998. An organizational psychology meta model of occupational stress. In Theories of organizational stress, ed. C.L. Cooper, 6 27. Oxford: Oxford University Press.

Beehr, T.A. 1976. Perceived moderators of the relationship between subjective role ambiguity and role strain. Journal of Applied Psychology 61, no. 1: 3540.

Behling, O., and K.S. Law. 2000. Translating questionnaires and other research instruments: Problems and solutions. Thousand Oaks, CA: Sage.

Bettencourt, L.A. 2004. Change oriented organizational citizenship behaviors: The direct and moderating influence of goal orientation. Journal of Retailing 80, no. 3: 16580.

Bliese, P.D., R.R. Halverson, and C.A. Schriesheim. 2002. Benchmarking multilevel methods in leadership. The articles, the model, and the data set. The Leadership Quarterly 13, no. 1: 314.

Bolon, D.S. 1999. Level of analysis considerations in organizational citizenship behavior research: An empirical investigation of individual work group effects among hospital employees. Health Services Management Research 12, no. 2: 92108.

Büssing, A., and J. Glaser. 1999. Work stressors in nursing in the course of redesign: Implications for burnout and interactional stress. European Journal of Work and Organizational Psychology 8, no. 3: 40126.

Carmeli, A., and J. Weisberg. 2006. Exploring turnover intentions among three professional groups of employees. Human Resource Development International 9, no. 2: 191206.

Cobb, C.W. 1976. Social support as moderator of life stress. Psychosomatic Medicine 38, no. 5: 300 14.

Conger, J.A. 1989. The charismatic leader: Behind the mystique of exceptional leadership. San Francisco, CA: Jossey Bass Publishers.

DAK BGW, ed. 2000. Krankenpflegereport Arbeitsbedingungen und Gesundheit von Pflegekräften in der Bundesrepublik [Report on nursing: Working conditions and health of nurses in Germany]. Hamburg: DAK.

De Cremer, D., and D. Van Knippenberg. 2002. How do leaders promote cooperation? The effects of charisma and procedural fairness. Journal of Applied Psychology 87, no. 5: 85866.

De Hoogh, A.H.B., D.N. den Hartog, P.L. Koopman, H. Thiery, P.T. van den Berg, J.G. van der Weide, and C.P.M. Wilderon. 2004. Charismatic leadership, environmental dynamism, and performance. European Journal of Work and Organizational Psychology 13, no. 4: 44771.

De Jonge, J., and C. Dormann. 2006. Stressors, resources, and strain at work: A longitudinal test of the triple match principle. Journal of Applied Psychology 91, no. 6: 135974.

De Vries, R.E., R.A. Roe, and T.C.B. Taillieu. 1999. On charisma and need for leadership. European Journal of Work and Organizational Psychology 8, no. 1: 10933.

Deckop, J.R., R. Mangel, and C.C. Cirka. 1999. Getting more than you pay for: Organizational citizenship behavior and pay for performance plans. Academy of Management Journal 42, no. 4: 4208.

DeGroot, T., D.S. Kiker, and T.C. Cross. 2000. A meta analysis to review organizational outcomes related to charismatic leadership. Canadian Journal of Administrative Sciences 17, no. 4: 35671 . 
Deluga, R.J. 1995. The relationship between attributional charismatic leadership and organizational citizenship behaviour. Journal of Applied Social Psychology 25, no. 18: 165269.

Den Hartog, C.N., A.E. Keegan, and A.H.B. De Hoogh. 2007. Research reports. The interactive effects of belongingness and charisma on helping and compliance. Journal of Applied Psychology 92, no. 4: 11319.

Den Hartog, D.N., and R.M. Verburg. 1997. Charisma and rhetoric: Communicative techniques of international business leaders. Leadership Quarterly 8, no. 4: 35591.

Densten, I.L. 2005. The relationship between visioning behaviors of leaders and follower burnout. British Journal of Management 16, no. 2: 10518.

Dvir, T., D. Eden, B.J. Avolio, and B. Shamir. 2002. Impact of transformational leadership on follower development and performance: A field experiment. Academy of Management Journal 45, no. 4: 73544.

Frese, M., S. Beimel, and S. Schoenborn. 2003. Action training for charismatic leadership: Two evaluations of studies of a commercial training module on inspirational communication of a vision. Personnel Psychology 56, no. 3: 67197.

Fuller, J.B., E.P. Coleman, K.H. Patterson, and D. Stringer. 1996. A quantitative review of research on charismatic leadership. Psychological Reports 78, no. 1: 27187.

Gebert, D. 1981. Belastung und Beanspruchung in Organisationen [Stressors and Strain in Organizations]. Stuttgart: Carl Ernst Poeschel Verlag.

Glazer, S. 2005. Six of one, half a dozen of the other: Problems with working fixed and rotating shifts. International Journal of Stress Management 12, no. 2: 14263.

Gore, S. 1978. The effect of social support in moderating the health consequences of unemployment. Journal of Health and Social Behavior 19, no. 2: 15765.

Gray Toft, P., and J.G. Anderson. 1981. The nursing stress scale: Development of an instrument. Journal of Behavioral Assessment 3, no. 1: 1123.

Hallin, K., and E. Danielson. 2007. Registered nurses' experiences of daily work, a balance between strain and stimulation: A qualitative study. International Journal of Nursing Studies 44, no. 7: 122130.

Hipwell, A.E., P.A. Tyler, and C.M. Wilson. 1989. Sources of stress and dissatisfaction among nurses in four hospital environments. British Journal of Medical Psychology 62, no. 1: 719.

House, R., W.D. Spangler, and J. Woycke. 1991. Personality and charisma in the US presidency: A psychological theory of leader effectiveness. Administrative Science Quarterly 36, no. 3: 36496.

Howell, J.M., and P.J.U. Frost. 1989. A laboratory study of charismatic leadership. Organizational Behavior and Human Decision Processes 43, no. 2: 24369.

Jaccard, J., and R. Turrisi. 2003. Interaction effects in multiple regression. Thousand Oaks, CA: Sage.

Judge, T.A., E.F. Woolf, C. Hurst, and B. Livingston. 2006. Charismatic and transformational leadership. Zeitschrift für Arbeits und Organisationspsychologie 50, no. 4: 20314.

Kark, R., B. Shamir, and G. Chen. 2003. The two faces of transformational leadership: Empowerment and dependency. Journal of Applied Psychology 88, no. 2: 24655.

Keller, R.T. 1992. Transformational leadership and the performance of research and development project groups. Journal of Management 18, no. 3: 489501.

Kirkpatrick, S.A., and E.A. Locke. 1996. Direct and indirect effects of three core charismatic leadership components on performance and attitudes. Journal of Applied Psychology 81, no. 1: 3651.

Kominis, G., and C. Emmanuel. 2007. The expectancy valence theory revisited: Developing an extended model of managerial motivation. Management Accounting Research 18, no. 1: 4975.

Konovsky, M.A., and D.W. Organ. 1996. Dispositional and contextual determinants of organizational citizenship behaviour. Journal of Organizational Behavior 17, no. 3: 25366.

Koslowski, M. 1998. Modeling the stress strain relationship in work settings. London: Routledge.

Lazarus, R.S. 1991. Emotion and adaptation. New York: Oxford University Press.

Lowe, K.B., K.G. Kroeck, and N. Sivasubramaniam. 1996. Effectiveness correlates of transforma tional and transactional leadership: A meta analytic review of the MLQ literature. Leadership Quarterly 7, no. 3: 385425.

MacKenzie, S.B., P.M. Podsakoff, and M. Ahearne. 1998. Some possible antecedents and consequences of in role and extra role salesperson performance. Journal of Marketing 62, no. 3: 8798.

McAlearney, A.S. 2006. Leadership development in healthcare: A qualitative study. Journal of Organizational Behavior 27, no. 7: 96782.

McDonald, R.P. 1999. Test theory: A unified treatment. Mahwah, NJ: Lawrence Erlbaum. 
McNeese Smith, D. 1999. The relationship between managerial motivation, leadership, nurse outcomes and patient satisfaction. Journal of Organizational Behavior 20, no. 2: 24359.

Organ, D.W. 1988. Organizational citizenship behavior: The good soldier syndrome. Lexington, MA: Lexington Books.

., and K. Ryan. 1995. A meta analytic review of attitudinal and dispositional predictors of organizational citizenship behaviour. Personnel Psychology 48, no. 4: 775802.

Patterson, C., J.B. Fuller, K. Kester, and D.Y. Stringer. 1995. A meta analytic examination of leadership style and selected follower compliance outcomes. Paper presented at the 18th meeting of the Society for Industrial and Organizational Psychology, Orlando, FL.

Payne, R. 1999. Stress at work: A conceptual framework. In Stress in health professionals, ed. J. Firth Cozens and R.L. Payne, 3 16. Chichester: John Wiley \& Sons Ltd.

Podsakoff, P.M., S.B. MacKenzie, J.B. Paine, and D.G. Bachrach. 2000. Organizational citizenship behaviors. A critical review of the theoretical and empirical literature and suggestions for future research. Journal of Management 26, no. 5: 51363.

., J.Y. Lee, and N.P. Podsakoff. 2003. Common method biases in behavioral research: A critical review of the literature and recommended remedies. Journal of Applied Psychology 88, no. 5: 879903.

., R.H. Moorman, and R. Fetter. 1990. Transformational leader behavior and their effects on followers' trust in leader, satisfaction, and organization citizenship behaviours. The Leadership Quarterly 1, no. 2: 10742.

., and W.H. Bommer. 1996. Transformational leader behaviors and substitutes for leadership as determinants of employee satisfaction, commitment, trust, and organizational citizenship behaviours. Journal of Management 22, no. 2: 25998.

Porter, L.W., and G.B. McLaughlin. 2006. Leadership and the organizational context: Like the weather? The Leadership Quarterly 17, no. 6: 55976.

Rowold, J., and K. Heinitz. 2007. Transformational and charismatic leadership: Assessing the convergent, divergent and criterion validity of the MLQ and the CKS. The Leadership Quarterly 18, no. 2: 12133 .

Russ Eft, D. 2001. Workload, stress, and human resource development. Human Resource Development Quarterly 12, no. 1: 13.

Schat, A.C.H., K.E. Kelloway, and S. Desmarais. 2005. The Physical Health Questionnaire (PHQ): Construct validation of a self report scale of somatic symptoms. Journal of Occupational Health Psychology 10, no. 4: 36381.

Schirmer, L., and F. Lopez. 2001. Probing the social support and work strain relationship among adult workers: Contributions of adult attachment orientations. Journal of Vocational Behavior 59, no. 1: 1733 .

Shamir, B., M. Arthur, and R.J. House. 1994. The rhetoric of charismatic leadership: A theoretical extension, a case study, and implications for research. Leadership Quarterly 5, no. 1: 2542 .

., R.J. House, and M.B. Arthur. 1993. The motivational effects of charismatic leadership: A self concept based theory. Organization Science 4, no. 3: 57794.

., E. Zakay, E. Breinin, and M. Popper. 1998. Correlates of charismatic leader behavior in military units: Subordinates' attitudes, unit characteristics, and superiors' appraisals of leader performance. Academy of Management Journal, 41, no. 4: 387409.

Siegall, M. 2000. Putting the stress back into role stress: Improving the measurement of role conflict and role ambiguity. Journal of Managerial Psychology 15, no. 5: 42735.

Singh Kang, L., and R. Singh. 2004. Identifying stressors at work a case of employees in electronics industry. Decision 31, no. 1: 5172.

Sobel, M.E. 1982. Asymptotic confidence intervals for indirect effects in structural equation models. In Sociological methodology, ed. S. Leinhardt, 290 312. Washington, DC: American Sociological Association.

Sosik, J. 2005. The role of personal values in the charismatic leadership of corporate managers: A model and preliminary field study. Leadership Quarterly 16, no. 2: 22144.

Staufenbiel, T., and C. Hartz. 2000. Organizational citizenship behavior: Entwicklung und erste Validierung eines Meßinstrumentes [Organizational citizenship behavior: Development and first validation of an instrument]. Diagnostica 46, no. 2: 7383.

Terry, D.J., and N.L. Jimmieson. 1999. Work control and employee well being: A decade review. International Review of Industrial and Organizational Psychology 14: 95148. 
Todorovic, Z.W., and F.K. Schlosser. 2007. An entrepreneur and a leader! A framework conceptualizing the influence of leader style on a firm's entrepreneurial orientation performance relationship. Journal of Small Business and Entrepreneurship 20, no. 3: 289308.

Tyler, P.A., D. Carroll, and S.E. Cunningham. 1991. Stress and well being in nurses: A comparison of the public and private sectors. International Journal of Nursing Studies, 28, no. 2: 12530 .

Udris, I., and M. Frese. 1999. Belastung und Beanspruchung [Stress and strain]. In Arbeits und Organisationspsychologie [Work and organizational psychology], ed. C.G. Hoyos and D. Frey, 429 45. Weinheim: Beltz PVU.

Vroom, V.H. 1964. Work and motivation. New York: Wiley.

Waldman, D.A., G.G. Ramirez, R.J. House, and P. Puranam. 2001. Does leadership matter? CEO leadership attributes and profitability under conditions of perceived environmental uncertainty. Academy of Management Journal 44, no. 1: 13443.

Werner, J.M. 2000. Implications of OCB and contextual performance for human resource management. Human Resource Management Review 10, no. 1: 324.

Winwood, P., and K. Lushington. 2006. Disentangling the effects of psychological and physical work demands on sleep, recovery and maladaptive chronic stress outcomes within a large sample of Australian nurses. JAN Journal of Advanced Nursing 56: 67989.

Yammarino, F.J., F. Dansereau, and C.J. Kennedy. 2001. A multiple level multidimensional approach to leadership: Viewing leadership through an elephant's eye. Organizational Dynamics 29, no. 3: 14963.

Yukl, G. 1999. An evaluation of conceptual weakness in transformational and charismatic leadership theories. The Leadership Quarterly 10, no. 2: 285305.

Zellars, K.L., P.L. Perrewé, W.A. Hochwarter, and K.S. Anderson. 2006. The interactive effects of positive affect and conscientiousness on strain. Journal of Occupational Health Psychology 11, no. 3: 2819 . 